Review

\title{
Role of $Y$ Box Protein-1 in cancer: As potential biomarker and novel therapeutic target
}

\author{
Pramod Kumar Maurya ${ }^{1}$, Alok Mishra ${ }^{1}$, Birendra Singh Yadav ${ }^{1}$, Swati Singh ${ }^{2}$, Prashant Kumar ${ }^{1}$, Amit \\ Chaudhary ${ }^{1}$, Shweta Srivastava ${ }^{1}$, Suriya Narayan Murugesan ${ }^{1}$, Ashutosh Mani ${ }^{1 凶}$ \\ 1. Department of Biotechnology, MNNIT Allahabad-211004 \\ 2. Center of Bioinformatics, University of Allahabad, Allahabad-211002 \\ $\triangle$ Corresponding author: E-mail: amani@mnnit.ac.in \\ (c) Ivyspring International Publisher. This is an open access article distributed under the terms of the Creative Commons Attribution (CC BY-NC) license \\ (https://creativecommons.org/licenses/by-nc/4.0/). See http://ivyspring.com/terms for full terms and conditions.
}

Received: 2016.09.24; Accepted: 2017.02.03; Published: 2017.07.03

\begin{abstract}
The Y-box binding protein (YB-1) is known to be a multifunctional transcription and translation factor during expression of several proteins. It is a vital oncoprotein that regulates cancer cell progression and proliferation. YB-1 is over-expressed in various human cancers such as breast cancer, colon cancer, lung cancer, gastric cancer, oesophageal cancer and glioblastoma. Nuclear expression of YB-1 is found to be associated with multidrug resistance and cancer cell progression. YB-1 is reported to regulate many cellular signalling pathways in different types of cancer proliferation. Knowledge about nuclear localization and nuclear level expression of YB-1 in different cancers has been correlated with prospective prognosis of cancer. This review discusses the prospects of YB-1 as a potential biomarker as well as therapeutic target in lieu of their role during cancer progression and multidrug resistance.
\end{abstract}

Key words: Y Box Protein-1, cancer, biomarker

\section{Introduction}

YB-1 (Y-box binding protein-1) is a cold shock domain protein which is a member of a large family of proteins containing a highly conserved nucleic acid binding motif called cold shock domain (CSD) of about 65 amino acids [1]. YB-1 is primarily localized in cytoplasm but it is localized to nucleus in response to various stresses, including hyperthermia [2], adenoviral infection [3], DNA damage [4] and activation of PI3K, Akt and RSK signalling [5].

Initially, it was identified to bind with the Y-box or inverted CCAAT box of MHC class II promoter and play an important role in inhibition of gene transcription [6]. Later, it was identified that YB-1 binds with the Y-box present in the enhancer and promoter region of a wide variety of genes such as EGFR and HER-2 genes and regulate the transcription [7]. Thereafter, YB-1 was also found to bind with CT-rich elements in the C-myc promoter [8]. Several subsequent studies have shown that YB-1 either up-regulate or down-regulate the expression of many important genes such as multidrug resistance 1 , cyclin A, cyclin B1, collagen alpha2(I) and matrix metalloproteinase $2[9,10,4]$.

However, YB-1 is generally present in the cytoplasm and associated with mRNA as mRNP to perform mRNA masking and regulation of translation but studies suggest that concentration of YB-1 also regulates the translation, as low concentration of YB-1 activates translation and high concentration represses it $[11,12]$. In nucleus and cytoplasm, YB-1 regulates the mRNA metabolism at various steps such as transcription, translation, splicing and mRNA stability.

\section{Structure of YB-1}

The Y-box binding protein-1 is a 324 amino acid-long protein having molecular mass of $35.9 \mathrm{kDa}$ which comprises of three domains: alanine/proline-rich variable N-terminal domain (A/P domain), a highly conserved nucleic-acid 


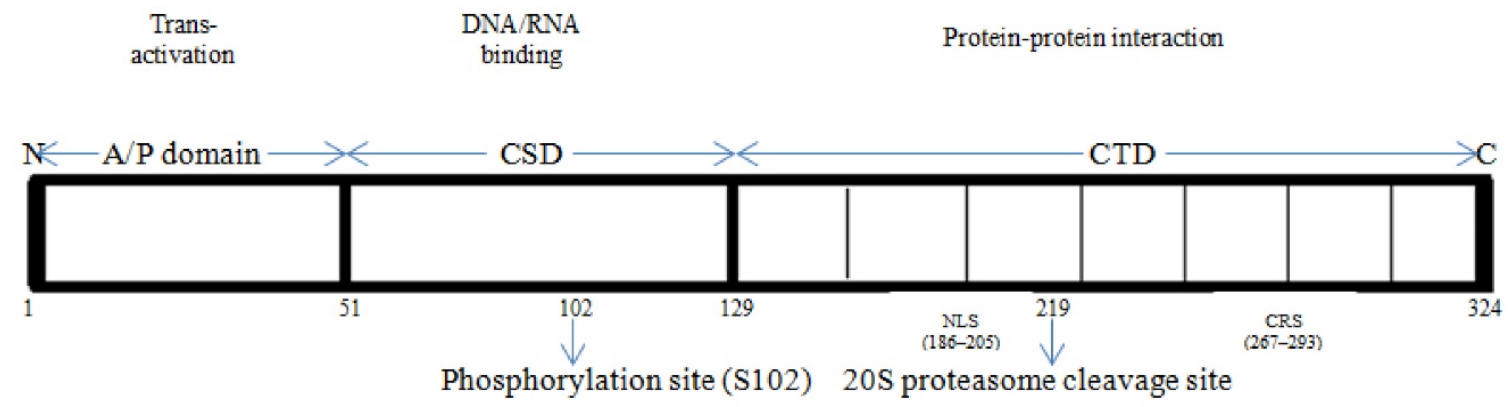

Fig 1: Structural organization of YB-1

binding cold shock domain (CSD) and a large disordered C-terminal domain (CTD) containing alternating clusters of positively and negatively charged amino acids [13]. The CTD also contains nuclear localization signal (NLS), the cytoplasmic retention site (CRS), and the $20 \mathrm{~S}$ proteasome cleavage site [14, 15]. The studies suggest that the cold shock domain (CSD) has a tertiary structure containing a five-stranded $\beta$-barrel with consensus sequences [16] and associated with both specific and unspecific binding with nucleic acid [14]. The CTD has binding sites for both nucleic acid and a number of proteins $[17,18,19,20]$.

The A/P domain has disordered structure and it contains binding sites for splicing factor SRp30c [21], actin [22], cyclin D1 [23] and transcription factor p53 [19]. The CSD domain has binding sites for Akt kinase [5], PDK-1, RSK and E3 ubiquitin ligase FBX33 [24]. The C-terminal domain (CTD) has disordered structure containing alternate regions of basic or acidic amino acids, having about 30 amino acids in length, called a B/A repeat and is involved in protein homo-multimerization [25, 26]. The CTD has binding sites for several important regulatory proteins such as hnRNP D [27], hnRNP K [28], Tata binding protein (TBP) [28], PCNA (Proliferating cell nuclear antigen) [18], EWS (Ewing's sarcoma breakpoint region) and TLS (Translocated in liposarcoma protein) [29], transcription factor p53 [19], E3 ubiquitin ligase RBBP6 [30] and IRP 2 (Iron regulatory protein 2) [31].

\section{Functions of YB-1}

YB-1, a multifunctional protein, has multiple roles in regulating transcription and translation of a wide range of important genes and proteins in cancer cell proliferation and progression [32], cell survival [33, 34, 35, 36], DNA replication [37], DNA repair [17], multi-drug resistance $[38,2]$ and epithelialmesenchymal transition [39]. As nucleic acid binding protein, YB-1 performs diverse biological functions such as transcriptional and translational regulation, pre-mRNA splicing, chromatin remodelling and environmental stress response $[4,40]$.

\section{Translation}

In order to regulate the transcription, YB-1 either act as a transcription factor by binding to the Y-box sequences present in the promoters and enhancer regions of a wide range of genes and subsequently activate or repress the gene transcription or act as a co-activator/co-repressor to interact with the other transcription factors. The genes activated by YB-1 are EGFR, HER-2, thymidine kinase, multidrug resistance 1 (MDR1), protein tyrosine phosphatase 1B, proliferating cell nuclear antigen (PCNA), cyclin A and cyclin B1, gelatinase A, Smad7 gene, PI3KCA gene, matrix metalloproteinase 2 and DNA topoisomerase II alpha. Genes which are transcriptionally repressed by YB-1 are MHC class II, collagen alpha1, VEGF, Fas, granulocyte-macrophage colony-stimulating factor (GMCSF), LRP/MVP gene, p21 gene and thyrotropin receptor gene [41, 4, 42]. YB-1 play an important role in regulating growth and stress response related genes.

\section{Splicing}

YB-1 regulates the selection of splicing site by recognition of splicing specific motifs in pre mRNA containing A/C-rich exon enhancers [43] or by association with splicing factors of SR family [44, 21].

\section{mRNA translation and stability}

YB-1 is a major component of mRNPs (messenger ribonucleoprotein particles), as it activates or represses the translation in a dose-dependent manner with mRNA i.e. YB-1/mRNA ratio [11]. YB-1 plays an important role in regulating the translational activity of several growth related mRNA such as HIF1a, LEF-1, Snail 1 and 2, ZEB2 [45, 39]. Due to its chaperone activity, it protects capped mRNA from degradation [46]. YB-1 also regulates the stabilization of transient mRNA by activating several genes including GMCSF $[47,48,49]$.

\section{DNA repair and stress response}

YB-1 regulates both base-excision repair and mismatch repair pathways by conducting multiple 
associations with 1 DNA repair proteins such as glycosylase NEIL2, DNA ligase III, DNA polymerase beta and delta, MSH2, Ku80, APE1, WRN, endonuclease III [50, 51, 17]. YB-1 also regulates separation of DNA strands in case of mismatch repairs or mutation caused by drugs $[18,52,51]$. The nuclear localization of YB-1 and its proteasomal cleavage [53] is also found to be associated with a number of physiological stresses such as DNA damage, hyperthermia and adenovirus infection [54, 4]. The over-expression of YB-1 protein in nucleus is correlated with the increased multi-drug resistance and cell survival $[4,53]$. The YB-1 obtained from fibroblast embryos has shown a reduction in respond to oxidative, oncogene-induced and genotoxic stresses [55]. The studies show that YB-1 is an important protein in stress responses as well as during early and late embryonic development [56].

\section{Tumorigenesis}

The overexpression of YB-1 is reported in various types of human cancers [4, 57]. In multiple human cancers, the increased expression level of YB-1 is correlated with multi-drug resistance and poor outcomes [58,59]. In breast cancer cells, the increased level of YB-1 induces tumour growth and invasiveness $[5,60]$. The increased levels of YB-1 has been associated with DNA topoisomerase II activity, proliferating cell nuclear antigen (PCNA) expression in human colorectal cancer [61], lung cancer [62] and cell proliferation in osteosarcoma [63]. YB-1 has a specific role in inhibiting the PI3K or Akt-induced oncogenic transformation [64] and it has been correlated with cytosolic localization and protein synthesis $[65,66]$. Thus YB-1 may play crucial role in blocking the translation of growth-related proteins such as kinases, receptors, growth factors and several regulatory proteins of PI3K and Akt pathways [67].

\section{Role of YB-1 in cancer regulation and proliferation}

The multifunctional regulatory protein YB-1 is activated by the phosphorylation at serine 102 position [68]. On phosphorylation, YB-1 shuttles from cytoplasm to nucleus where it becomes an oncogenic transcription factor by inducing the expression of growth-promoting genes such as EGFR [69], HER-2 [70], PCNA [18], Cyclin A, Cyclin B [10] as well as also affects the expression of multidrug resistance gene [71].

YB-1 expression level was reported to be highly associated with the cancer cell progression and proliferation [58]. YB-1 was found to be correlated with the expression of many important genes including genes for providing unlimited growth, drug resistance, overriding cell cycle and controlling gene transcription and translation in cancer cells [72, 4]. Such genes which are overexpressed in cancer, have $Y$ -box or CCAAT box sequence in their promoter or enhancer region [73, 74]. YB-1 binds to the Y-box sequence of these genes and trans-activate their expression [75]. For example, YB-1 trans-activates the MDR1 gene, containing $Y$ or CCAAT- box sequence in its promoter region and cause overexpression of MDR1gene. The high MDR1 gene level associated with nucleus YB-1 is reported in case of many types of human cancer such as osteosarcoma, breast, lung, prostate, and synovial sarcoma cancer [76-83].

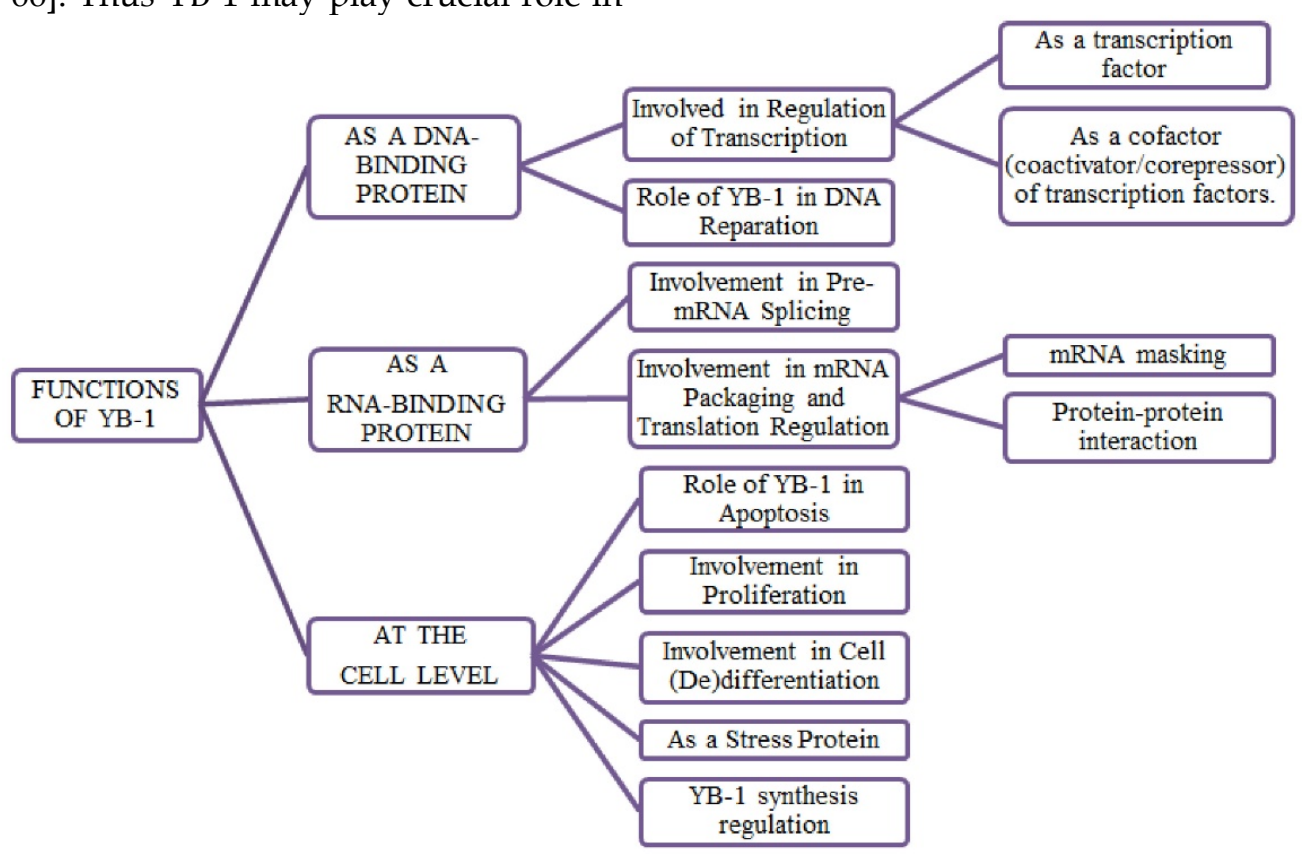

Fig 2: Functions of YB-1 
Besides strong correlation with MDR1, the nucleus YB-1 level was reported to co-regulate the growth promoting genes [72]. The multifunctional protein YB-1 has multiple effects on cancer cells by regulating the all the nine "Hallmarks of Cancer" as described by Hanahan and Weinberg [84, 14]. In order to modulate the cell signalling pathways to promote or maintain malignancy in cancer cell, YB-1 plays important role in each hallmark of cancer that are uncontrolled proliferation signalling, evading growth suppressors and cell cycle checkpoints, resisting cell death and evading immune destructions [85, 86, 87].

The YB-1 reduction causes growth repression and apoptosis in a large number of cancer cells such as breast, colon, lung and prostate cancer [87]. The reduction in YB-1 expression was found to be correlated with the inhibition of cancer progression, cell growth and promotion of apoptosis in a wide range of human cancer cells such as- Melanoma, Fibrosarcoma, liver cancer, lung cancer, breast cancer, colon cancer, prostate cancer and paediatric glioblastoma [88, 89]. YB-1 blocks Fas-mediated apoptosis pathway at multiple points to prevent apoptosis [33]. YB-1 promotes uncontrolled cancer cell proliferation by activation of E2F pathways which is a prevalent event in almost all types of cancers [89]. YB-1 inhibits the expression of RB in many ways and also reported to inhibit the expression of p53 gene in cancer cells hence reduce tumour suppression activity $[90,34]$.

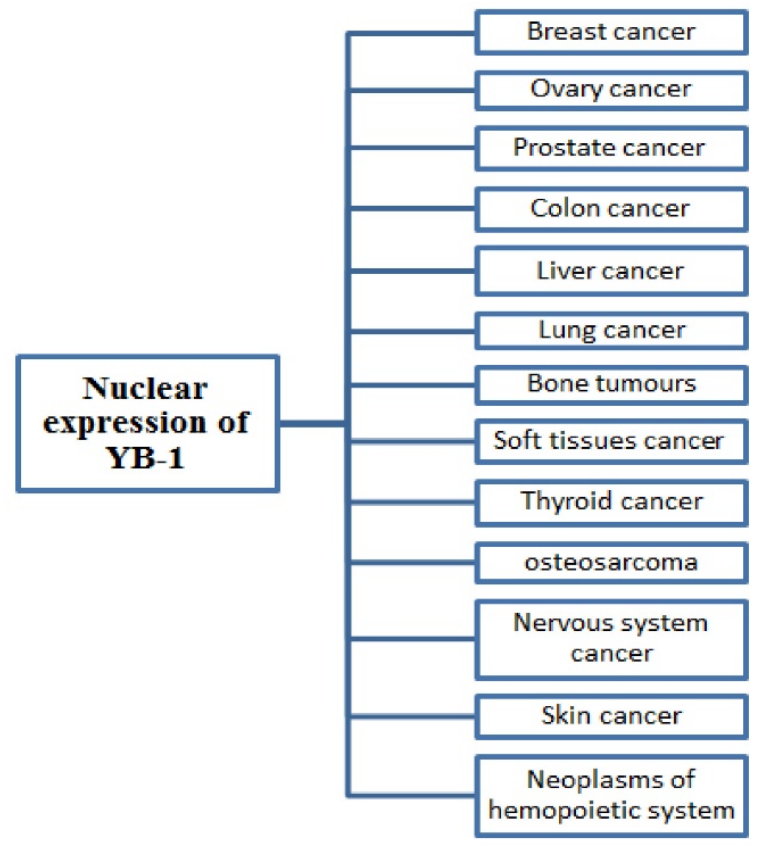

Fig 3: Prognostic association of YB-1 with different types of malignancies
Table 1: The functions of YB-1 in different Cancers

\begin{tabular}{|c|c|c|}
\hline S.No. & Hallmarks of Cancer & Regulated gene/Pathways \\
\hline 1 & $\begin{array}{l}\text { Uncontrolled Proliferation } \\
\text { Signalling }\end{array}$ & $\begin{array}{l}\text { Regulates E2F pathways } \\
\text { Regulates PI3K/Akt/mTOR pathway } \\
\text { Regulates Ras/Raf/MEK/ERK } \\
\text { pathway } \\
\text { Regulates MAPK pathway }\end{array}$ \\
\hline 2 & $\begin{array}{l}\text { Evading Growth Suppressors } \\
\text { and cell cycle checkpoints }\end{array}$ & $\begin{array}{l}\text { Inhibits RB (gatekeeper protein) } \\
\text { pathway } \\
\text { Inhibits p53 (tumour suppressor } \\
\text { protein) pathway }\end{array}$ \\
\hline 3 & Resisting cell death & $\begin{array}{l}\text { Inhibits BAX and CASP7-mediated } \\
\text { apoptosis } \\
\text { Inhibit Fas-mediated apoptosis } \\
\text { pathway } \\
\text { Proliferation of E2F target genes }\end{array}$ \\
\hline 4 & $\begin{array}{l}\text { Enabling replicative } \\
\text { immortality }\end{array}$ & $\begin{array}{l}\text { Activation of telomere maintenance } \\
\text { mechanism } \\
\text { Loss of RB checkpoints } \\
\text { Loss of p53 function }\end{array}$ \\
\hline 5 & Inducing angiogenesis & $\begin{array}{l}\text { Activate pro-angiogenic genes such as } \\
\text { VEGF-A, FDGF-B, IL-8, CXCL-2 }\end{array}$ \\
\hline 6 & $\begin{array}{l}\text { Activating invasion and } \\
\text { metastasis }\end{array}$ & $\begin{array}{l}\text { Regulates SNAI1, LEF1 and TWIST1 to } \\
\text { repress CDH1 gene (E-cadherin) } \\
\text { Regulate TGF- } \beta \text {, Wnt pathway proteins } \\
\text { and Notch } 3 \text { receptor }\end{array}$ \\
\hline 7 & $\begin{array}{l}\text { Deregulating energy } \\
\text { metabolism }\end{array}$ & $\begin{array}{l}\text { Regulating PI3K/Akt/mTOR, Myc, } \\
\text { PKM2, RB/E2F1 and p53 pathway }\end{array}$ \\
\hline 8 & Evading immune dystruction & $\begin{array}{l}\text { Regulation of gene encoding MHC } \\
\text { Class II and Fas } \\
\text { Regulation of TGF- } \beta \text { pathway }\end{array}$ \\
\hline 9 & $\begin{array}{l}\text { Tumour promoting } \\
\text { inflammation }\end{array}$ & $\begin{array}{l}\text { Regulates expression of mTOR, STAT3 } \\
\text { MMP-2, CD44, CCL5 AND CCL2 }\end{array}$ \\
\hline
\end{tabular}

\section{YB-1 as a potential bio-marker}

The nucleus expression level of YB-1 is a prognostic biomarker for cancer progression, cell proliferation and multidrug resistance in various human cancers [91]. YB-1 promotes the transcription of proliferation/growth-promoting genes in the nucleus while in cytoplasm, it is found to be associated with mRNA and involved in direct translation.

In different human cancer such as breast, lung, prostate, liver, colon and others, the nuclear expression of YB-1 is associated with poor clinical outcomes. These reports suggest that YB-1 is an important biomarker to predict the patient's prognosis and is feasible for identifying the particular stage treatment protocol $[4,14]$. While using YB-1 as a prognostic tool in human cancer, the cellular localization of YB-1 in cell (cytoplasm/nucleus) or the nuclear YB-1 expression level may be used to predict the particular stage of cancer $[87,91]$.

Many studies have focused on the correlation between overall YB-1 levels and the prognosis of patient. Several studies over time have shown that the overexpression and nuclear localization of YB-1 is also associated with different human cancers such as breast cancer [58], lung cancer [92], liver cancer [93], ovarian cancer [94], colorectal cancer [61], prostate 
cancer [95], Synovial sarcoma [96], multiple myeloma [90], osteosarcoma [63], melanoma [97], glioblastoma [98]. Several studies suggested that YB-1 in most of the cancers is nuclear localized and its identification and quantification in cancer cells make YB-1 a powerful prognostic marker. Many studies also shows that overall YB-1 level (cytoplasmic and nuclear) is an efficient predictor for prognosis of cancer $[90,59,99]$.

\section{YB-1 as a novel therapeutic target}

Many molecular targets have been identified in different human cancers that lead to the establishment of therapeutic approaches [100] as HER-2 in breast cancer [101] and TREK-1 in prostate cancer [102]. YB-1 may be a novel therapeutic target for cancers as it is upstream of the many genes involved in cellular signalling pathways including drug resistance gene (MDRI) as well as other growth related genes such as HER-2, EGFR, proliferating nuclear antigen (pcna), cyclin A, and cyclin B which are responsible for cancer development [100]. Various approaches have been employed to target YB-1 either by directly inhibiting the activation of $\mathrm{YB}-1$ or targeting the activators which activate YB-1 such as PI3K, AKT, PDK and RSK.

The molecular decoy of YB-1 binding site has been successfully used in different cultured cells, showing the inhibition of tumour growth and induction of p53-mediated apoptosis [34, 35]. The development cell permeable peptide (CPP) in cancer has shown to block the YB-1 phosphorylation and down-regulate of growth-promoting genes EGFR and HER-2 which in turn caused $90 \%$ cancer inhibition in growth of breast and prostate cancer [103].

The second approach is to directly target the YB-1 by using siRNA and the anti YB-1 siRNAs which has been successfully employed to transfect different cancer cells and shown inhibition of tumour growth, proliferation, differentiation and enhanced apoptosis [90, 89, 104, 105, 106]. This approach involves challenge to deliver siRNA in human including limitation of stability, bioavailability, delivery technologies and understanding molecular chemistry [107].

SiRNAs against YB-1 have been used to block the YB-1 phosphorylation and reduce proliferation in breast cancer [104, 36], lung cancer [108], prostate cancer [109], mesangial cancer [37] and myeloma [90, 110] cell lines. When activated by phosphorylation at serine 102, YB-1 gets nuclear localized, acts as transcription factor and causes overexpression of growth-promoting genes and multidrug resistance genes [5]. Mutation at phosphorylation site by i.e. Ser102 by substituting it to Ala102 shows inhibition of
YB-1 nuclear localization and suppression in tumour growth [36].

Another approach to indirectly target the YB-1 is to influence the signal transduction or the activator kinases which phosphorylate the protein to suppress its activity in cancer cells. The blocking of kinases like Akt [45, 5], PDK-1 [111] and RSK [112] has shown reduced YB-1 phosphorylation and transactivation activity. Although Akt play a key role in phosphorylating the YB-1 [5], but when compared to other kinases RSK play a major role in activation of YB-1 [112, 113].

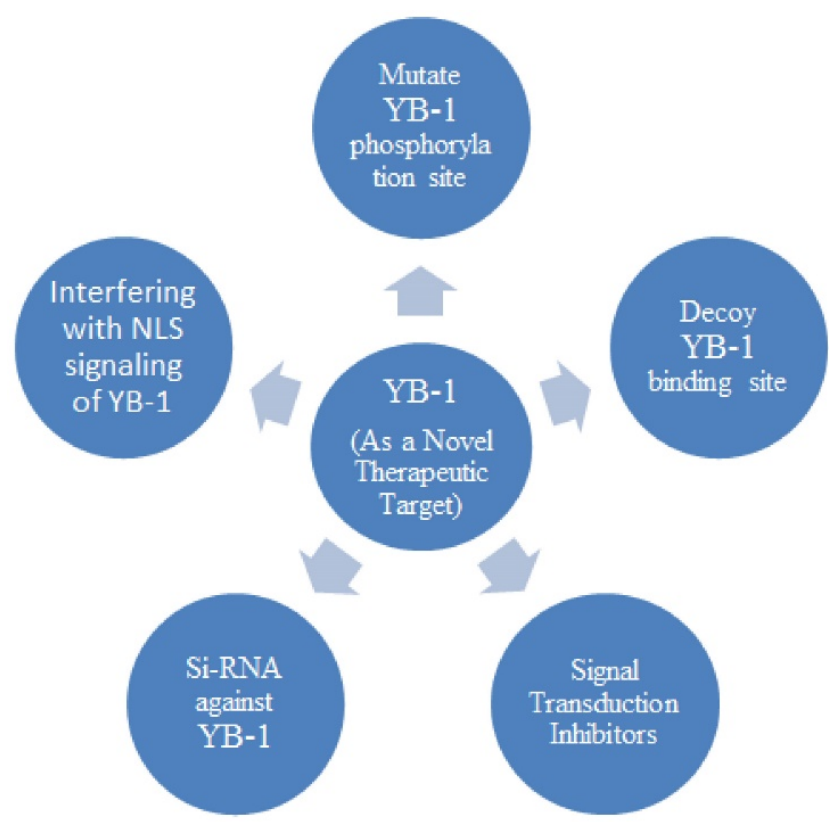

Fig 4: Targeting of YB-1

A hypothetical therapeutic approach to target the YB-1 in cancer cell may be to inhibit the NLS (Nuclear Localization Signal) signalling pathway by simply mutating the NLS site located in the protein. This may prove to be a promising strategy to reduce YB-1 nuclear localization as well as to suppress tumour growth, although there is no significant information available about this signalling pathway and more investigations are needed in this regard. However complete regulatory network information of the protein will certainly be more helpful in identifying a target which directly or indirectly influences variations in the protein expression level or controls the nuclear localization. Direct targeting of YB-1 may not prove to be a promising approach when compared to the indirect targeting, as blocking of kinases PI3K, Akt, PDK-1 and RSK would cause blockage of YB-1 that may cause severely adverse side effects due to their vital role in cellular signalling pathways, making this therapy less feasible. 


\section{Conclusion}

This review discusses the role of multifunctional YB-1 protein in human cancer biology and mode of regulation of each hallmark of cancer by YB-1. YB-1 is an oncogenic transcription and translation regulator which plays key role in different cellular processes. Further investigations are needed to gain insights of complete function and regulation of YB-1 during proliferation of cancer. In different cancers, the level of YB-1 is correlated with poor clinical outcomes; hence YB-1 may serve as a potential biomarker for cancer progression. The level of YB-1 present in nucleus and cytoplasm of several human cancer cells generally predict the prognosis of cancer.

Despite of rapid technological advances the function and regulation mechanism of YB-1 are not known completely. Being a constitutively expressing protein, targeting the protein as such may be harmful for healthy cells, however targeted drug delivery may be a suitable technique for this purpose.

\section{Acknowledgement}

This work has been supported by a grant from SERB, Department of Science and Technology, Government of India under Young Scientist Scheme.

Author contributions: PKM, AM1, BSY, SS1, PK, $\mathrm{AC}, \mathrm{SS} 2, \mathrm{SNM}$ and AM2 helped in manuscript writing. All the authors contributed equally.

\section{Competing Interests}

\section{Authors declare no conflicts of interest.}

\section{References}

1. Wolffe AP, Tafuri S, Ranjan M, Familari M. The Y-box factors: a family of nucleic acid binding proteins conserved from Escherichia coli to man. New Biol. 1992; 4:290-298.

2. Stein U, Jurchott K, Walther W, Bergmann S, Schlag PM, Royer HD. Hyperthermia-induced nuclear translocation of transcription factor YB1 leads to enhanced expression of multidrug resistance related $A B C$ transporters. J Biol Chem. 2001; 276:28562-28569.

3. Holm PS, Bergmann S, Jurchott K, et al. YB-1 relocates to the nucleus in adenovirus infected cells and facilitates viral replication by inducing E2 gene expression through the E2 late promoter. J Biol Chem. 2002; 277:10427-10434.

4. Kohno K, Izumi H, Uchiumi T, Ashizuka M, Kuwano M. The pleiotropic functions of the Y-box-binding protein, YB-1. Bioessays. 2003; 25:691-698.

5. Sutherland BW, Kucab J, Wu J, et al. Akt phosphorylates the Y-box binding protein 1 at Ser102 located in the cold shock domain and affects the anchorage independent growth of breast cancer cells. Oncogene. 2005; 24:4281-4292.

6. Didier DK, Schiffenbauer J, Woulfe SL, Zacheis M, Schwartz BD. Characterization of the cDNA encoding a protein binding to the major histocompatibility complex class II Y box. Proc Natl Acad Sci USA. 1988; 85:7322-7326.

7. Sakura H, Maekawa T, Imamoto F, et al. Two human genes isolated by a novel method encode DNA-binding proteins containing a common region of homology. Gene. 1988; 73:499-507.

8. Kolluri R, Kinniburgh AJ. Full length cDNA sequence encoding a nuclease-sensitive element DNA binding protein. Nucleic Acids Res. 1991; 19:4771.

9. Higashi $\mathrm{K}$, Inagaki $\mathrm{Y}$, Suzuki N, et al. Y-box-binding protein $\mathrm{YB}-1$ mediates transcriptional repression of human alpha 2(I) collagen gene expression by interferon-gamma. J Biol Chem. 2003; 278:5156-62.

10. Jurchott K, Bergmann S, Stein U, et al. YB-1 as a cell cycle-regulated transcription factor facilitating cyclin $\mathrm{A}$ and cyclin $\mathrm{B} 1$ gene expression. J Biol Chem. 2003; 278:27988-96.
11. Evdokimova VM, Ovchinnikov LP. Translational regulation by Y-box transcription factor: involvement of the major mRNA-associated protein, p50. Int J Biochem Cell Biol. 1999; 31:139-149.

12. Guryanov SG, Filimonov VV, Timchenko AA, et al. The major mRNP protein YB-1: structural and association properties in solution. Biochim Biophys Acta. 2012; 1834:559-567.

13. Cohen SB, Ma W, Valova VA, et al. Genotoxic stress-induced nuclear localization of onco-protein YB-1 in the absence of proteolytic processing. Oncogene. 2010; 29:403-410.

14. Eliseeva IA, Kim ER, Guryanov SG, Ovchinnikov LP, Lyabin DN. Y-box-binding protein 1 (YB-1) and its functions. Biochemistry (Mosc). 2011; 76:1402-1433.

15. Kloks CP, Spronk CA, Lasonder $\mathrm{E}$, et al. The solution structure and DNA-binding properties of the colds hock domain of the human Y-box protein YB-1. J Mol Biol. 2002; 316:317-326.

16. Landsman D. RNP-1, an RNA-binding motif is conserved in the DNA-binding cold shock domain. Nucleic Acids Res. 1992; 20:2861-2864.

17. Das S, Chattopadhyay R, Bhakat KK, et al. Stimulation of NEIL2-mediated oxidized base excision repair via YB-1 interaction during oxidative stress. J Biol Chem. 2007; 282:28474-28484.

18. Ise $T$, Nagatani $G$, Imamura $T$, et al. Transcription factor $Y$-box binding protein 1 binds preferentially to cisplatin-modified DNA and interacts with proliferating cell nuclear antigen. Cancer Res. 1999; 59:342-346.

19. Okamoto $\mathrm{T}$, Izumi $\mathrm{H}$, Imamura $\mathrm{T}$, et al. Direct interaction of $\mathrm{p} 53$ with the Y-box binding protein YB-1: amechanism for regulation of human gene expression. Oncogene. 2000; 19:6194-6202.

20. Skabkin MA, Kiselyova OI, Chernov KG, et al. Structural organization of mRNA complexes with major core mRNP protein YB-1. Nucleic Acids Res. 2004; 32:5621-5635.

21. Raffetseder U, Frye B, Rauen T, et al. Splicing factor SRp30c interaction with Y-box protein1 confers nuclear YB1 shuttling and alternative splice site selection. J Biol Chem. 2003; 278:18241-18248.

22. Ruzanov PV, Evdokimova VM, Korneeva NL, Hershey JW, Ovchinnikov LP. Interaction of the universal mRNA-binding protein, p50, with actin: a possible link between mRNA and microfilaments. J Cell Sci. 1999; 112:3487-3496.

23. Khandelwal P, Padala MK, Cox J, Guntaka RV. The N-terminal domain of Y-box binding protein-1 induces cell cycle arrest in G2/M phase by binding to cyclin D1. Int J Cell Biol. 2010; 2009:243532.

24. Lutz M, Wempe F, Bahr I, Zopf D, von Melchner H. Proteasomal degradation of the multifunctional regulator YB-1 is mediated by an F-Box protein induced during programmed cell death. FEBS Lett. 2006; 580:3921-30.

25. Tafuri SR, Wolffe AP. DNA binding, multimerization, and transcription stimulation by the Xenopus Y box proteins in vitro. New Biol. 1992; 4:349-359.

26. Murray MT. Nucleic acid-binding properties of the Xenopus oocyte Y-box protein mRNP3+4. Biochemistry. 1994; 33:13910-13917.

27. Moraes KCM, Quaresma AJC, Maehnss K, Kobarg J. Identification and characterization of proteins that selectively interact with isoforms of the mRNA binding protein AUF1 (hnRNP D). Biological chemistry. 2003; 384:25-37.

28. Shnyreva M, Schullery DS, Suzuki H, Higaki Y, Bomsztyk K. Interaction of two multifunctional proteins. Heterogeneous nuclear ribonucleoprotein $\mathrm{K}$ and Y-box-binding protein. J Biol Chem. 2000; 275:15498-15503.

29. Chansky HA, Hu M, Hickstein DD, Yang L. Oncogenic TLS/ERG and EWS/Fli-1 Fusion Proteins Inhibit RNA Splicing Mediated by YB-1 Protein. Cancer Res. 2001; 61:3586-3590.

30. Chibi M, Meyer M, Skepu A, Rees DJ, Moolman-Smook JC, Pugh DJ. RBBP6 interacts with multifunctional protein YB-1 through its RING finger domain, leading to ubiquitination and proteosomal degradation of YB-1. J Mol Biol. 2008; 384:908-916.

31. Ashizuka M, Fukuda T, Nakamura T, et al. Novel translational control through an iron-responsive element by interaction of multifunctional protein YB-1 and IRP2. Mol Cell Biol. 2002; 22:6375-6383.

32. Mertens PR, Harendza S, Pollock AS, Lovett DH. Glomerular mesangial cell-specific transactivation of matrix metalloproteinase 2 transcription is mediated by YB-1. J Biol Chem. 1997; 272:22905-22912.

33. Lasham A, Lindridge E, Rudert F, Onrust R, Watson J. Regulation of the human fas promoter by YB-1, Puralpha and AP-1 transcription factors. Gene. 2000; 252:1-13

34. Lasham A, Moloney S, Hale T, et al. The Y-box-binding protein, YB1, is a potential negative regulator of the p53 tumor suppressor. J Biol Chem. 2003; 278:35516-35523.

35. Homer C, Knight DA, Hananeia L, Sheard P, Risk J, Lasham A, Royds JA, Braithwaite AW. Y-box factor YB1 controls p53 apoptotic function. Oncogene. 2005; 24:8314-8325.

36. Wu J, Lee C, Yokom D, et al. Disruption of the Y-box binding protein-1 results in suppression of the epidermal growth factor receptor and HER-2. Cancer Res. 2006; 66:4872-4879.

37. En-Nia A, Yilmaz E, Klinge U, Lovett DH, Stefanidis I, Mertens PR. Transcription factor YB-1 mediates DNA polymerase alpha gene expression. J Biol Chem. 2005; 280:7702-7711.

38. Goldsmith ME, Madden MJ, Morrow CS, Cowan KH. A Y-box consensus sequence is required for basal expression of the human multidrug resistance (mdr1) gene. J Biol Chem. 1993; 268:5856-5860. 
39. Evdokimova $\mathrm{V}$, Tognon $\mathrm{C}, \mathrm{Ng} \mathrm{T}$, et al. Translational activation of snail1 and other developmentally regulated transcription factors by YB-1 promotes an epithelial-mesenchymal transition. Cancer Cell. 2009; 15:402-415.

40. Matsumoto K, Bay BH. Significance of the Y-box proteins in human cancers. J Mol Genet Med. 2005; 1:11-17.

41. Ladomery $\mathrm{M}$, Sommerville J. A role for $\mathrm{Y}$-box proteins in cell proliferation. Bioessays. 1995; 17:9-11.

42. Makino $\mathrm{Y}$, Ohga $\mathrm{T}$, Toh $\mathrm{S}$, et al. Structural and functional analysis of the human Y-box binding protein (YB-1) gene promoter. Nucleic Acids Res. 1996; 24:1873-1878.

43. Stickeler E, Fraser SD, Honig A, Chen AL, Berget SM, Cooper TA. The RNA binding protein $\mathrm{YB}-1$ binds $\mathrm{A} / \mathrm{C}$-rich exon enhancers and stimulates splicing of the CD44 alternative exon v4. EMBO J. 2001; 20:3821-3830.

44. Li J, Hawkins IC, Harvey CD, Jennings JL, Link AJ, Patton JG. Regulation of alternative splicing by SRrp86 and its interacting proteins. Mol Cell Biol. 2003; 23:7437-7447.

45. Evdokimova V, Ruzanov P, Anglesio MS, Sorokin AV, Ovchinnikov LP, Buckley J, Triche TJ, Sonenberg N, Sorensen PH. Akt-mediated YB-1 phosphorylation activates translation of silent mRNA species. Mol Cell Biol. 2006; 26:277-292.

46. Evdokimova $\mathrm{V}$, Ruzanov $\mathrm{P}$, Imataka $\mathrm{H}$, et al. The major mRNA associated protein YB-1 is a potent $5^{\prime}$ cap-dependent mRNA stabilizer. EMBO J. 2001; 20:5491-5502.

47. Capowski EE, Esnault S, Bhattacharya S, Malter JS. Y box binding factor promotes eosinophil survival by stabilizing granulocyte-macrophage colony-stimulating factor mRNA. J Immunol. 2001; 167:5970-5976.

48. Chen CY, Gherzi R, Andersen JS, Gaietta G, Jurchott K, Royer HD, Mann M, Karin M. Nucleolin and YB-1 are required for JNK-mediated interleukin2 mRNA stabilization during Tcell activation. Genes Dev. 2000; 14:1236-1248.

49. Coles LS, Bartley MA, Bert A, Hunter J, Polyak S, Diamond P, Vadas MA, Goodall GJ. A multiprotein complex containing cold shock domain (Ybox) and polypyrimidine tract binding proteins forms on the vascular endothelial growth factor mRNA, Potential role in mRNA stabilization. Eur J Biochem. $2004 ; 271: 648-660$.

50. Marenstein DR, Ocampo MT, Chan MK, Altamirano A, Basu AK, Boorstein RJ, Cunningham RP, Teebor GW. Stimulation of human endonuclease III by Y-box binding protein 1 (DNA-binding protein B), Interaction between a base excision repair enzyme and a transcription factor. J Biol Chem. 2001; 276:21242-21249.

51. Gaudreault I, Guay D, Lebel M. YB-1 promotes strand separation in vitro of duplex DNA containing either mispaired bases or cisplatin modifications, exhibits endonucleolytic activities and binds several DNA repair proteins. Nucleic Acids Res. 2004; 32:316-327.

52. Skabkin MA, Evdokimova V, Thomas AA, Ovchinnikov LP. The major messenger ribonucleoprotein particle protein p50 (YB1) promotes nucleic acid strand annealing. J Biol Chem. 2001; 276:44841-44847.

53. Sorokin AV, Selyutina AA, Skabkin MA, et al. Proteasome-mediated cleavage of the Y-box binding protein-1 is linked to DNA damage stress response. EMBO J. 2005; 24:3602-3612.

54. Ohga T, Koike K, Ono M, et al. Role of the human Y-box binding protein YB-1 in cellular sensitivity to the DNA damaging agents cisplatin, mitomycin $\mathrm{C}$, and ultraviolet light. Cancer Res. 1996; 56:4224-4228.

55. Lu ZH, Books JT, Ley TJ. YB1 is important for latest-age embryonic development, optimal cellular stress responses, and the prevention of premature senescence. Mol Cell Biol. 2005; 25:4625-4637.

56. Lu ZH, Books JT, Ley TJ. Cold shock domain family members YB-1 and MSY4 share essential functions during murine embryogenesis. Mol Cell Biol. 2006; 26:8410-8417.

57. Kuwano $\mathrm{M}$, Uchiumi $\mathrm{T}$, Hayakawa $\mathrm{H}$, et al. The basic and clinical implications of ABC transporters, Y-box binding protein-1 (YB-1) and angiogenesis related factors in human malignancies. Cancer Sci. 2003; 94:9-14.

58. Bargou RC, Jurchott $K$, Wagener $C$, et al. Nuclear localization and increased levels of transcription factor $\mathrm{YB}-1$ in primary human breast cancers are associated with intrinsic MDR1 gene expression. Nat Med. 1997; 3:447-450.

59. Janz M, Harbeck N, Dettmar P, et al. Y-box factor YB-1 predicts drug resistance and patient outcome in breast cancer independent of clinically relevant tumor biologic factors HER2, UPA and PAI1. Int J Cancer. 2002; 97:278-282.

60. Bergmann S, RoyerPokora B, Fietze E, et al. YB-1 provokes breast cancer through the induction of chromosomal instability that emerges from mitotic failure and centrosome amplification. Cancer Res. 2005; 65:4078-4087.

61. Shibao K, Takano H, Nakayama Y, et al. Enhanced coexpression of YB-1 and DNA topoisomerase IIa genes in human colorectal carcinomas. Int J Cancer. 1999; 83:732-737.

62. Gu C, Oyama T, Osaki T, Kohno K, Yasumoto K. Expression of Y box-binding protein-1 correlates with DNA topoisomerase II alpha and proliferating cell nuclear antigen expression in lung cancer. Anticancer Res. 2001; 21:2357-2362.

63. Oda Y, Sakamoto A, Shinohara N, et al. Nuclear expression of YB-1 protein correlates with P-glycoprotein expression in human osteosarcoma. Clin Cancer Res. 1998; 4:2273-2277.

64. Bader AG, Felts KA, Jiang N, Chang HW, Vogt PK. Y box-binding protein 1 induces resistance to oncogenic transformation by the phosphatidylinositol 3-kinase pathway. Proc Natl Acad Sci USA. 2003; 100:12384-12389.

65. Bader AG, Vogt PK. An essential role for protein synthesis in oncogenic cellular transformation. Oncogene. 2004; 23:3145-3150.
66. Bader AG, Vogt PK. Inhibition of protein synthesis by Y-box binding protein 1 blocks oncogenic cell transformation. Mol Cell Biol. 2005; 25:2095-2106.

67. Zimmer SG, DeBenedetti A and Graff JR. Translational control of malignancy: the mRNA cap-binding protein, eIF- $4 \mathrm{E}$, as a central regulator of tumor formation, growth, invasion and metastasis. Anticancer Res. 2000; 20:1343-1351.

68. Stratford AL, Fry CJ, Desilets C, et al. Y-box binding protein- 1 serine 102 is a downstream target of p90 ribosomal S6 kinase in basal-like breast cancer cells. Breast Cancer Research. 2008; 10:R99.

69. Stratford AL, Habibi G, Astanehe A, et al. Epidermal growth factor receptor (EGFR) is transcriptionally induced by the Y-box binding protein-1 (YB-1) and can be inhibited with Iressa in basal-like breast cancer, providing a potential target for therapy. Breast Cancer Research. 2007; 9:R61.

70. Shibata T, Kan H, Murakami Y, et al. Y-box binding protein-1 contributes to both HER2/ErbB2 expression and lapatinib sensitivity in human gastric cancer cells. Mol Cancer Ther. 2013; 12:737-746.

71. Vaiman AV, Stromskaya TP, Rybalkina EY, et al. Intracellular localization and content of YB-1 protein in multidrug resistant tumor cells. Biochemistry. 2006; 71:146-154.

72. Basaki $\mathrm{Y}$, Taguchi K, Izumi H, et al. Y-box binding protein-1 (YB-1) promotes cell cycle progression through CDC6-dependent pathway in human cancer cells. European Journal of Cancer. 2010; 46:954-965.

73. Marino-Ramirez L, Spouge JL, Kanga GC, Landsman D. Statistical analysis of over-represented words in human promoter sequences. Nucleic Acids Res. 2004; 32:949-958.

74. Fitzgerald PC, Shlyakhtenko A, Mir AA, Vinson C. Clustering of DNA sequences in human promoters. Genome Res. 2004; 14:1562-1574.

75. Dolfini D, Mantovani R. Targeting the Y/CCAAT box in cancer: YB-1 (YBX1) or NF-Y. Cell Death and Differentiation. 2013; 20:676-685.

76. Tabach Y, Milyavsky M, Shats I, et al. The promoters of human cell cycle genes integrate signals from two tumor suppressive pathways during cellular transformation. Mol Syst Biol. 2005; 1:1-15.

77. Salvatore G, Nappi TC, Salerno P, et al. A cell proliferation and chromosomal instability signature in anaplastic thyroid carcinoma. Cancer Res. 2007; 67:10148-10158.

78. Scafoglio C, Ambrosino C, Cicatiello L, et al. Comparartive gene expression profiling reveals partially overlapping but distinct genomic actions of different anti-estrogens in human breast cancer cells. J Cell Biochem. 2006; 98:1163-1184.

79. Niida A, Smith AD, Imoto S, et al. Integrative bioinformatics analysis of transcriptional regulatory programs in breast cancer cells. BMC Bioinform. 2008; 9:404.

80. Thomassen M, Tan Q, Kruse TA. Gene expression meta-analysis identifies metastatic pathways and transcription factors in cancer. BMC Cancer. 2008; 8:394.

81. Blum R, Gupta R, Burger PE, et al. Molecular signatures of prostate stem cells reveal novel signaling pathways and provide insights into prostate cancer. PLoS One. 2009; 4:e5722.

82. Calvo A, Perez-Stable C, Segura V, et al. Molecular characterization of the Ggamma-globin-Tag transgenic mouse model of hormone refractory prostate cancer: comparison to human prostate cancer. The Prostate. 2010; 70:630-645.

83. Forsberg EC, Passegué E, Prohaska SS, et al. Molecular signatures of quiescent, mobilized and leukemia-initiating hematopoietic stem cells. PLoS One. 2010; 5:e8785.

84. Brandt S, Raffetseder U, Djudjaj S, et al. Cold shock Y-box protein-1 participates in signalling circuits with auto-regulatory activities. Eur J Cell Biol. 2012; 91:464-471.

85. Hanahan D, Weinberg RA. The hallmarks of cancer. Cell. 2000; 100:57-70

86. Hanahan D, Weinberg RA. Hallmarks of cancer: the next generation. Cell. 2011; 144:646-674.

87. Lasham A, Print CG, Woolley AG, Dunn SE, Braithwaite AW. YB-1: oncoprotein, prognostic marker and therapeutic target. Biochem J. 2013; 449:11-23.

88. Basaki Y, Hosoi F, Oda Y, et al. Akt-dependent nuclear localization of Y-box-binding protein 1 in acquisition of malignant characteristics by human ovarian cancer cells. Oncogene. 2007; 26:2736-2746.

89. Lasham A, Samuel W, Cao H, et al. YB-1, the E2F pathway, and regulation of tumor cell growth. J Natl Cancer Inst. 2012; 104:133-146.

90. Chatterjee M, Rancso C, Stuhmer T, et al. The Y-box binding protein YB-1 is associated with progressive disease and mediates survival and drug resistance in multiple myeloma. Blood. 2008; 111:3714-3722.

91. Kosnopfel C, Sinnberg T, Schittek B. Y-box binding protein 1-a prognostic marker and target in tumour therapy. Eur J Cell Biol. 2014; 93:61-70.

92. Shibahara K, Sugio K, Osaki T, et al. Nuclear expression of the Y-box binding protein, YB-1, as a novel marker of disease progression in non-small cell lung cancer. Clin Cancer Res. 2001; 7:3151-3155.

93. Yasen M, Kajino K, Kano S, et al. The up-regulation of Y-box binding proteins (DNA binding protein A and Y-box binding protein-1) as prognostic markers of hepatocellular carcinoma. Clin Cancer Res. 2005; 11:7354-7361.

94. Kamura T, Yahata H, Amada S, et al. Is nuclear expression of $\mathrm{Y}$ box-binding protein-1 a new prognostic factor in ovarian serous adenocarcinoma. Cancer. 1999; 85:2450-2454.

95. Gimenez-Bonafe P, Fedoruk MN, Whitmore TG, et al. YB-1 is upregulated during prostate cancer tumor progression and increases P-glycoprotein activity. Prostate. 2004; 59:337-349. 
96. Oda Y, Ohishi Y, Saito T, et al. Nuclear expression of Y-box-binding protein-1 correlates with P-glycoprotein and topoisomerase II a expression, and with poor prognosis in synovial sarcoma. J Pathol. 2003; 199:251-258.

97. Schittek B, Psenner K, Sauer B, Meier F, Iftner T, Garbe C. The increased expression of $Y$ box-binding protein-1 in melanoma stimulates proliferation and tumor invasion, antagonizes apoptosis and enhances chemoresistance. Int J Cancer. 2007; 120:2110-2118.

98. Faury D, Nantel A, Dunn SE, et al. Molecular profiling identifies prognostic subgroups of pediatric glioblastoma and shows increased YB-1 expression in tumors. J Clin Oncol. 2007; 25:1196-1208.

99. Yoshimatsu T, Uramoto H, Oyama T, et al. Y-box-binding protein-1 expression is not correlated with p53 expression but with proliferating cell nuclear antigen expression in non-small cell lung cancer. Anticancer Res. 2005; 25:3437-3443.

100. Wu J, Stratford AL, Astanehe A, Dunn SE. YB-1 is a transcription/translation factor that orchestrates the oncogenome by hardwiring signal transduction to gene expression. Translat Oncogen. 2007; 2:1-17.

101. Sorlie T, Perou CM, Tibshirani R, et al. Gene expression patterns of breast carcinomas distinguish tumor subclasses with clinical implications. Proc Natl Acad Sci USA. 2001; 98:10869-10874

102. Voloshyna I, Besana A, Castillo M, et al. TREK-1 is a novel molecular target in prostate cancer. Cancer Res. 2008; 68:1197-1203.

103. Law JH, Li Y, To K, Wang M, Astanehe A, et al. Molecular Decoy to the Y-Box Binding Protein-1 Suppresses the Growth of Breast and Prostate Cancer Cells whilst Sparing Normal Cell Viability. PLoS ONE. 2010; 5:e12661.

104. Lee C, Dhillon J, Wang MY, et al. Targeting YB-1 in HER-2 overexpressing breast cancer cells induces apoptosis via the mTOR/STAT3 pathway and suppresses tumor growth in mice. Cancer Res. 2008; 68:8661-8666.

105. Fotovati A, Abu-Ali S, Wang PS, et al. YB-1 bridges neural stem cells and brain tumor-initiating cells via its roles in differentiation and cell growth. Cancer Res. 2011; 71:5569-5578.

106. Gao Y, Fotovati A, Lee C, et al. Inhibition of Y-box binding protein-1 slows the growth of glioblastoma multiforme and sensitizes to temozolomide independent O6-methylguanine-DNA methyltransferase. Mol Cancer Ther. 2009; 8:3276-3284.

107. Seton-Rogers S. Therapeutics: siRNAs jump the hurdle. Nat Rev Cancer. 2012; 12:376-377.

108. Basaki Y, Taguchi $\mathrm{K}$, Izumi H, et al. Y-box binding protein-1 (YB-1) promotes cell cycle progression through CDC6-dependent pathway in human cancer cells. Eur J Cancer. 2010; 46:954-965.

109. Shiota $M$, Izumi $H$, Onitsuka $T$, et al. Twist promotes tumor cell growth through YB-1 expression. Cancer Res. 2008; 68:98-105.

110. Cobbold LC, Wilson LA, Sawicka K, et al. Upregulated c-myc expression in multiple myeloma by internal ribosome entry results from increased interactions with and expression of PTB-1 and YB-1. Oncogene. 2010; 29:2884-2891.

111. To K, Zhao $\mathrm{Y}$, Jiang $\mathrm{H}$, et al. The phosphoinositide-dependent kinase-1 inhibitor 2-amino-N-\{4-[5-(2-phenanthrenyl)-3-(trifluoromethyl)-1H-pyrazol-yl]phenyl\}- acetamide (OSU-03012) prevents Y-box binding protein-1 from inducing epidermal growth factor receptor. Mol Pharmacol. 2007; 72:641-652.

112. Stratford AL, Fry CJ, Desilets C, et al. Y-box binding protein- 1 serine 102 is a downstream target of p90 ribosomal $\mathrm{S} 6$ kinase in basal-like breast cancer cells. Breast Cancer Res. 2008; 10:R99.

113. Lyabin DN, Eliseeva IA, Ovchinnikov LP. YB-1 protein: functions and regulation. Wiley Interdiscip Rev RNA. 2014; 5:95-110. 